Editorial

\title{
Gender Equality and Beyond: At the Crossroads of Neoliberalism, Anti-Gender Movements, "European" Values, and Normative Reiterations in the Nordic Model
}

\author{
Katarina Giritli Nygren ${ }^{1, *}$, Lena Martinsson ${ }^{2}$ and Diana Mulinari ${ }^{3}$ \\ ${ }^{1}$ Department of Social Sciences, Mid Sweden University, 5170 Sundsvall, Sweden; E-Mail: katarina.giritli-nygren@miun.se \\ 2 Department of Cultural Sciences, University of Gothenburg, 40530 Gothenburg, Sweden; E-Mail: lena.martinsson@gu.se \\ ${ }^{3}$ Department of Gender Studies, Lund University, 22100 Lund, Sweden; E-Mail: diana.mulinari@genus.lu.se \\ * Corresponding author
}

Submitted: 25 October 2018 | Published: 22 November 2018

\begin{abstract}
The social-democratic-inspired "Nordic model", with its agenda for gender equality, has been an important example for the development of political interventions to transform society but at the same time, it has functioned as an emerging gender normalising and stabilising structure. In the last decade it has also become the focus of antigender movements and ethno-nationalistic parties both as emblematic for the Nordic nations as well as a threat that must be destroyed to save the nation. This issue will elaborate further on gender equality as a node, a floating signifier in powerful and often contradictory discourses. We are inspired by scholarships of hope in a dialogue with articles that search for realistic utopias that might be considered to be "beyond gender equality". The included articles engage with the messiness and crossroads of gender equality in relation to the work-line, territories, neo-liberalism, religion, the crisis of solidarity and the success of anti-genderism agenda.
\end{abstract}

\section{Keywords}

anti-genderism; gender equality; neo-liberalism; racism

\section{Issue}

This editorial is part of the issue "Gender Equality and Beyond: At the Crossroads of Neoliberalism, Anti-Gender Movements, 'European' Values, and Normative Reiterations in the Nordic Model”, edited by Lena Martinsson (University of Gothenburg, Sweden), Diana Mulinari (Lund University, Sweden) and Katarina Giritli Nygren (Mid Sweden University, Sweden).

(C) 2018 by the authors; licensee Cogitatio (Lisbon, Portugal). This article is licensed under a Creative Commons Attribution 4.0 International License (CC BY).

\section{Introduction}

Gender equality is one of the cornerstones of Swedish society. The aim of Sweden's gender equality policies is to ensure that everyone enjoys the same opportunities, rights and obligations in all areas of life. (Sweden Government, 2018)

The above-mentioned quote reinforced by a picture of a young (white) man embracing a little child is the opening sentence of the Swedish government's website on gender equality. The quote illustrates the fundamental role that gender equality has within the Swedish society and culture and defines gender equality as an issue demanding equal rights and state concern. The ideology and policy practice of gender equality has been historically located within a social democratic frame through the establishment of public policies that supported women's work outside the home and through social policies aiming to balance paid work with family life. Gender equality policies that evolved after the sixties and seventies show a transformation of family forms from a male breadwinner model to a dual earning one with state financed childcare and policies aiming to include men in care work (Lundqvist, 2017). The (partially) accomplishment of these goals, aiming to decrease inequalities between 
women and men was (partially) achieved through a number of social movements (particularly the women's and the labour movement) and an entanglement between women's needs and the needs of the labour market.

Gender equality policies have since its implementation been at the core of feminist analysis. Gender scholars and feminists' activists pointed to the huge gap between policy reform and the lives of women that were, despite reforms, located within a gender segregated labour market and continued to be the main responsible for social reproductive work (Borchorst \& Siim, 2008). Different but fundamental readings were also provided by those feminist scholars that identified the normative regulation of heterosexuality and considered the nuclear family to be at the core of gender equality policies (Dahl, 2010; Martinsson, 2001) and by postcolonialism-inspired feminist scholars that named the appropriation of gender equality by ethnonationalist and value conservative social movements and political parties that redefined gender equality as a Western/Scandinavian value, which is threatened today by the Muslim Other (de los Reyes, Molina, \& Mulinari, 2014).

In line with this discussion, we published the book The Myth of Swedish Gender Equality (Martinsson, Griffin, \& Giritli Nygren, 2016; Mulinari, 2016). We argued that gender equality, as a state policy intervention, has not only contributed to recognise, once and for all, the vital feminist insight that the personal and the private is public and political but also that it can transform what might be understood as natural unequal gender orders as well as develop alternative gendered subjectivities, family forms, and societies. However, we maintained that gender equality state policies and practices are also a stabilising and even partly conservative force that reiterates and builds upon hetero-normative discourses, stable notions of traditional heterosexual nuclear families, and a recreation of gender binary notions. A binary "he" and "she" often implicitly becomes the transformative political subjects of gender equality and, as such, excludes other subject-positions. The gender equality norm also reproduces notions of Europe and the "Nordic model" as the crown of Enlightenment; they are framed by secularism and the Swedish modernity and held up as an example for others, such as racialised migrants and nations outside Europe, to assimilate to or follow.

Sweden as well as Nordic countries have, therefore, not only had an enviable reputation for gender equality politics and practices, but gender equality has also become an important aspect of the countries' self-image. Finally and central to the gender equality policies since its start is the integration of women into a capitalistregulated labour market based on a worldview that defines paid work as eternally and permanently empowering for women. It is through paid work that woman, but also the Swedish society, are supposed to become both equal and modern. Paid work plays a fundamental role in welfare rights, from parental leave to pensions. Citi- zenship is made through paid work, up to a certain point. Gender equality strategies and policies have, therefore, become inseparable from a capitalist regulated labour market. This merging of gender equality with paid work in order to create the good equal life is framed through the dynamics of financial capitalism, class inequalities, and, not least, the "work-line" (arbetslinjen) that makes paid work mandatory for access to welfare support. It makes it difficult for many who are not able to work full time, of whatever gender, to live liveable lives. And not the least, the hegemonic work-line makes it more difficult for other strategies and societal visions to emerge.

To summarise so far: what we want to underline is how gender equality and gender equality policies build on problematic notions and norms on gender, sexuality, nation, capitalism, and, workability. On the one side, these policies have been women friendly and have had a positive impact on the lives of some women or, rather, on their life choices, but they also have, on the other hand, simultaneously served to legitimise capitalist labour market relations and normalise heteronormative family forms, re-established differences between groups, and recreated Eurocentric, colonial, and nationalistic stories and orders.

In the last decade, gender equality has become the node for discourses at the core of three radical social transformations: 1 ) the shift in the earlier eighties from a social democratic regime to a neoliberal one with a reorganisation of the welfare state towards neoliberal frames (Therborn, 2018), 2) a transformation of the Swedish labour and migration policies to bridge neoliberalism with exclusion policies towards migrants and refugees (Schierup \& Ålund, 2011), and 3) an increase in the neo-Nazi mobilisations and a success of ethnonationalist political parties with strong anti-feminists' agendas (Norocel, 2010). The ethno-nationalist party Sweden Democrats understand gender equality as a European/Nordic value and argued that feminism and feminists not only destroyed men's masculinity and forced upon children the notion of gender that threatened the natural differences between the sexes but also supported multicultural societies that threatened the nation (Mulinari, 2016).

This decoupling of gender equality from feminism makes it possible to be pro gender equality (both in a neo-liberal and even neo-conservative frame) while at the same time resisting and questioning feminism as a project that vouches for inclusive and transnational social justice.

We have three aims with this issue. First, to elaborate further on gender equality as a node, a floating signifier in powerful and often contradictory discourses-it answers questions such as: what does this socio-political and affective messiness tell us not only about gender equality but also about its transnational and national contexts and imagined communities? Secondly, to explore the forms and dynamics through which gender equality is transformed in the production of forms of 
femo-nationalist (Farris, 2017), homo-nationalist (Puar, 2017), and the fundamental symbol of what ethnonatioalist parties identify as the "cultural Marxists and feminist lobby", a symbol that must be destroyed to save the nation, at the same time. Finally, we want to write ourselves within the tradition of scholarships of hope; thus, we will conclude the introduction through a dialogue about articles that search for realistic utopias (Wright, 2009) that might be considered to be "beyond gender equality".

\section{The Messiness and Crossroads}

As mentioned above, the social-democratic inspired "Nordic model" with its agenda for gender equality has been an important example for the development of political interventions to transform society but it has also been, at the same time, functioning as an emerging gender normalising and stabilising structure. It is its role as a floating signifier that provides the term gender equality with ongoing transformations in a society that it both takes part and constantly re-emerges with new meanings and performative effects. In the following section, we will outline the different crossroads and ongoing transformations that will be further explored in the contributing articles.

\subsection{Gender Equality and the Work-Line}

Feminist scholars have read the "Nordic model" through an exploration of the decommodification of care work, a decommodification that allows women's participation in paid work and allows a balance between family and work, making gender equality an honour and code word. It has upheld the welfare system and been part of its stabilising structure. This connection between work-line and gender equality is normative in a very material way, shaping and regulating whatever possible liveforms are desirable, excluding other lifeforms, and making invisible the diversity of labour practices outside the formal labour market. Many feminist scholars argue that it is important to deconstruct the relationship between gender equality and paid work in order to decouple gender equality from labour market demands.

Arguments for basic income models have been raised in order to make it easier to live outside these norms. In this volume, Koslowski and Duvander (2018) relate to this topic through the example of basic income and explore its potential to deconstruct the entanglement of paid work and consider paid work as a core value for gender equality. The authors thoroughly discuss what the basic income model might mean for gender equality. At the same time, as a basic income can be conceptualised as freedom, it is engendered and women's caring responsibilities could be reproduced if a base-income frame was secured. An independent core of income, the authors argue, is a way to attain autonomy, but it is not sufficient when it comes to challenging persistent gender norms.

\subsection{Gender Equality and Territories}

The understanding of gender equality as an idea, a policy, and a cultural practice emanating exclusively from the Global North has both disregarded the feminist struggles in the Global South and their contribution towards alternative forms of thinking, gender, and sexuality and reinforced the fantasy that gender equality is a Western cultural product embodied in the privilege of whiteness. To place gender equality, both temporally and spatially, as a modern western project and as one single movement coming from one place and spreading out in the world is, therefore, highly problematic (McDowell \& Sharp, 2016). We find it important to challenge the notion of feminism as a Western project in order to recognise and celebrate transnational feminist struggles searching for alternative notions of gender equality and social justice (Rivera Cusicanqui, 2010). Even if questions regarding territories, spaces, and borders and its re-organisation in times of neoliberalism and financial capital are present in nearly all articles in this issue, two articles particularly have a specific focus on gender equality and territories.

Roodsaz and Van Raemdonck (2018) explore how gender and sexuality understandings operate within developmental projects aimed to transfer one specific conceptualisation of gender equality from the Global North to the Global South. The authors locate their efforts in a productive dialogue with the scholarship situated on the interface of postcolonial critique, critical development studies, and feminist theories. They discuss the ability of such development projects to interact with local epistemologies, addressing how these projects aimed at (re)shaping subjectivities that fit into certain expectations often fail and arguing for a critical commitment by resisting homogeneity, closure, and universalism, which require an open attitude towards and an active search for alternative ontologies.

Sjöstedt Landén and Fotaki (2018) argue that it is important to uncover how the gender equality discourse may become instrumental to capitalist accumulation, including the "devastation of natural resources", "exploitation of human and non-human life", and reifications of "desirable and undesirable people". The authors bring up a similar issue but from a slightly different angle using analytical pairing of centres and peripheries when analysing how the gender equality projects are entangled with urban centres, highlighting the need to recognise (feminist) struggles for the defence of land and water in areas deemed peripheral across Europe, thereby challenging the urban mainstream gender equality discourse at national and EU levels.

\subsection{Gender Equality and Neo-Liberalism}

The notion that the "problem" with gender inequality could be solved not from within the socially and democratically framed state institutions and policies but with a "little help" from the market was a result of the merging 
of discourses and practices of gender equality with neoliberal agendas (Boreus, 1997). Even though the assigning of equality rights to women and other marginalised groups continued during the nineties, the neoliberal discourse introduced an "entrepreneurial culture" and notions of "welfare dependency" within a number of fundamental reforms in welfare policies and caused a shift from citizenship rights to affect the ways in which gender equality was interpreted and acted upon (Wottle \& Blomberg, 2011). Against the background of the national self-image of Sweden as gender equal and tolerant, concepts such as equal rights and gender equality were transformed towards important aspects of neoliberal discourses (Giritli Nygren, Fahlgren, \& Johansson, 2016). The crossroads between gender equality, specific spaces, and neoliberalism cut through many of the contributing articles in this issue.

Paula Mulinari (2018) explores the dialectic relationship between the representations of migrant women and their economic-political role as workers in the current phase of capitalism and further elaborates this topic. While she is inspired by a feminist postcolonial tradition, she wants to create bridges that link this central feminist intervention with the field of feminist political economy. The author also analyses how discourses on gender equality act upon racialised boundaries between and within city spaces and between and within different groups of women. She shows how labour market policies targeting migrant women located within what has been dominated "migrant neighbourhoods" are, in the name of gender equality, used not only to legitimise unequal access to social rights and create new categories of workers but also legitimate higher levels of exploitation in the labour market.

\subsection{Religion Contra Secularism}

In recent years, we have, as mentioned previously, seen an intensified tension in the hegemonic discourse between religion (coded as Islam) and secularism (Berg, Lundahl, \& Martinsson, 2016). The tension is used in diverse ways - not only to position religious beliefs against each other but also as an explanation for the growing threat of anti-feminism. The tension has been articulated in such a way as to homogenise the understanding about religion by excluding feminist transformative voices, key actors, and organisations challenging religious institutions from within (Kolankiewicz, 2015) and locating religion as patriarchal, traditional, and outside the scope of women's rights.

There is a fundamental need to transcend the binary opposition to the understanding of secularism as women friendly and the understanding of religion as a threat to feminist agendas, a binary opposition at the core of mainstream feminism and women's movement in Sweden. Three contributions in this issue deal with this crossroad and discuss the unified idea of gender equality as something that is tied to secularism.
Selin Çağatay (2018) uses examples from the Turkish context in order to criticise the way that secularism is understood, arguing for the need to shift the feminist analytical lens in the study of women's activism away from binary approaches to secularism and religion. The author shows how up until the 2010s, gender equality had been a central element in Turkey's official ideology and poses a fundamental question in the context of the authoritarian turn through the success of the ruling Justice and Development Party's (AKP): what are the underlying assumptions of gender equality struggles in relation to modernity, Westernisation, and religion? Such questions might also be useful in the Swedish context in order to destabilise what the author defines as the "mythical mantra of gender equality" and to highlight the affinity between the state, nationalism, secularism, and dominant understandings of gender equality.

Hannah Helseth (2018) analyses the rhetoric developed in the personal narrative written by self-defined Muslims when arguing for women's rights and the topos of individual autonomy. Her analysis shows how these accounts become personal when they argue for women's rights while, at the same time, meet with both the explicit and implicit demands to represent Muslims as a group. While the narratives provide examples of the diverse forms through which women themselves represent their identities, the category of "Muslim women" shapes and regulates what are possible subject positions. The author analyses the tension between the Western conceptualisation of individual autonomy and the actual representation of Muslim women that lacks this quality as a result of belonging to what racist discourses identify as collectivistic cultures.

Finally, Lena Gemzöe (2018), like Çağatay, blurs the supposed divide between secularism/equality and religion/oppression by focus on two feminist campaigns both connected to clothes-the Hijab Call-to-Action in defence of Muslim women's rights and a \#metoo manifestation whose uniting figure was the pussy bow blouse. The hijab campaign displayed how racist, islamophobic, anti-migration, and sexist attitudes constrain the possibility for Muslim women to live gender equal lives in Sweden. The Pussy Bow Blouse campaign with its connections to \#metoo and the Swedish Academy makes it clear that Sweden, despite its gender equality rhetoric, cannot provide safe places to women and secure women's rights to not being subjected to sexual violence.

\subsection{The Crisis of Solidarity and the Success of Anti-Genderism Agenda}

During the Swedish election campaign in 2018, the antifeminist and anti-gender rhetoric was made very explicit not only by the Sweden Democrats, the ethnonationalist party that gained a $17 \%$ electoral support and whose election program included the demand on stop for financial state support for scholarship on gender and racism, but also by other parties that followed and focussed 
their electoral campaigns on "gender nonsense (flum)", arguing that teachers influenced by feminist ideas violently take away cars from small boys and dolls from little girls by imposing a feminist agenda when gender differences are natural and said that challenging these differences intimidates children's healthy development (Sverker, 2018).

A violent and anti-Muslim agenda entangles this rhetoric where Islam is pointed out as a threat to the European values in general, specifically to the Swedish gender equality (Gardell, 2018; Kundnani, 2015; Listerborn, 2015). Muslim men, particularly, are systematically represented as dangerous for Swedish women, and the figure of "unaccompanied young boys" is used as an illustration of the chaos migration creates in the country. This anti-feminism/anti-gender and anti-Muslim and racist rhetoric is not completely new, but has moved from the periphery to the mainstream within the political field. This articulation appears today in new and radical (and more dangerous) forms (Eriksson, 2013) and acts upon a powerful entanglement of neoliberal ideologies and cultures, increasing the success of authoritarian, neo-fascist visions, ideas, and policies.

Despite the rhetoric that represents Sweden in international politics as a country inspired by feminism, Swedish international policies are at least partly to blame for the so-called refugee crisis as a result of its support to military intervention and its investment in profit driven and ecologically dangerous transnational corporations in the Global South. The public discourse in Sweden has changed from understanding refugees as a category of people in need of protection to defining them as a burden to the nation. We disagree with the assumption that Sweden is affected by a "refugee crisis", as external forces that recreate notions of racialised populations as dangerous could be the cause for the success of the ethnonationalist parties or the reason behind the social democratic regime crisis. We would rather speak of a crisis of solidarity in a country with a neoliberal culture that defines human needs in terms of market profits and a fundamentalist assimilationist agenda, where migrants are seen as in need of education of "Swedish values".

Lilja and Johansson (2018) seek in their contribution to this issue to respond to the challenges of antigenderism by exploring how the multitude of, and interlinkage between, different forms of resistance are intertwined in power, showing a discursive struggle where feminist critique and anti-genderism emerge and challenge one another as an unstable process. Through their analysis of different forms of resistance emerges a complicated network of power and resistance where a feminist resistance might even be caught in an impasse, risking strengthening the very power it protests against.

This theme is also discussed explicitly by Mathias Ericson (2018) who explores how the idealisation of Sweden as a modern and gender equal country is articulated in current processes of securitisation and nationalistic protectionism-showing how neoliberalism and
Swedish exceptionalism are entangled. This network or discursive emergence are also mobilised under the antigenderism agenda today, expressed through public discourses that link the stability of gender to exclusionary notions of nationhood and belonging.

\section{Important Implications for Future Feminist Theory and Practice-To Move Beyond}

How can feminism and gender studies at the local and the transnational level address the diverse contemporary forms of anti-genderism and the growing resistance to pluralistic and inclusive understanding of genders and sexualities?

First, we would argue that it is important to not fall back into nostalgic fantasies of the "Nordic model" and its gender equality frame, entangled, as we have argued, both in hetero-gender binary, and colonial frames by normalising a strong capitalist work line and creating boundaries between European values and its others. We also find it vital not to develop any form of binarity or divide between a monolithic notion of feminism and feminists as "good" and defending gender equality against racist and anti-gender movements. Everyday practices of class privilege racism and nationalism are also present among and within (some) feminism and (some) feminists in the Nordic countries, a support that fuels the more outspoken antigender and racist forces, and needs continuously to be addressed and explored.

Second, we asserted that while opposition to feminism and gender equality policies is not a new phenomenon, recent developments mark a distinctly new phase, strengthening or, in some cases, establishing new global and transnational regimes of oppression and exploitation that gender scholars and feminist activists need to respond to. These responses need to be located within a feminist transnational agenda (Kaplan \& Grewal, 2002; Mohanty, 2003) that has a commitment to both embodied local feminist knowledge and difficult and necessary conversations towards productive transnational feminist agendas.

Our third and concluding argument is that one of the core tasks of gender studies is to develop agendas for hope (Martinsson \& Mulinari, 2018), opening our imagination and putting forward fantasies, visions, and ideas about alternative inclusive and democratic futures. We believe, that solidarity across conflictual locations, experiences, and visions evolves from the political bridges that feminists create between and through diverse struggles. And, in order to deepen our understanding of the many complexities, challenges, and possibilities of different feminist struggles against diverse but highly connected regimes of oppression and exploitation, we have to call for transnational and intersectional dialogues and analysis.

We hope that the feminist works already present in the articles that analyse the complex ways through which gender equality despite being an important femi- 
nist vision; also entangles with class privilege, racism, sexism, and heteronormativity; allows us to imagine worlds that transcend politics of gender equality as a governability discourse in finance capitalism towards more inclusive futures.

\section{Acknowledgments}

The Swedish Research Council, through the reserch project Futures of Genders and Sexualities 2014:1418, has contributed to the founding.

\section{Conflict of Interests}

The authors declare no conflict of interests.

\section{References}

Berg, L., Lundahl, M., \& Martinsson, L. (2016). Sekularitet-Förstahet genom religion och kön [Secularism, hate through religion and gender]. Kvinder, Kön och Forskning, 2016(4), 7-19. https://doi.org/ 10.7146/kkf.v25i4.104394

Borchorst, A., \& Siim, B. (2008). Woman-friendly policies and state feminism. Feminist Theory, 9(2), 207-224.

Boreus, K. (1997). The shift to the right: Neo-liberalism in argumentation and language in the Swedish public debate since 1969. European Journal of Political Research, 31, 257-286.

Çağatay, S. (2018). Women's coalitions beyond the Laicism-Islamism divide in Turkey: Towards an inclusive struggle for gender equality? Social Inclusion, 6(4), 48-58.

Dahl, U. (2010). Rapport från Vithetshavet [Report from a sea of whiteness]. Tidskrift för Genusvetenskap, 2010(1/2). Advanced online publication. Retrieved from http://ojs.ub.gu.se/ojs/index.php/tgv/ article/view/779/718

de los Reyes, P., Molina, I., \& Mulinari, D. (Eds.). (2014). Maktens (o)lika förklädnader. Kön, klass \& etnicitet $i$ det postkoloniala Sverige [The diverse faces of power. Gender, class and ethnicity in postcolonial Sweden]. Stockholm: Arbetslivsinstitutet.

Eriksson, M. (2013). 'Wronged white men': The performativity of hate in feminist narratives about anti-feminism in Sweden. NORA: Nordic Journal of Feminist and Gender Research, 21(4), 249-263.

Ericson, M. (2018). "Sweden has been naïve": Nationalism, protectionism and securitisation in response to the refugee crisis of 2015. Social Inclusion, 6(4), 95-102.

Farris, S. (2017). In the name of women's rights. The rise of femonationalism. Durham: Duke University Press.

Gardell, M. (2018). Muslimer-Ett lovligt byte. Mattias Gardell om minoriteten som förföljs, trakasserasoch brännmärks av politiker och media [Muslims are fair game. Mattias Gardell on minorities being pursued, harassed and branded by politicians and the media]. Aftonbladet. Retrieved from www.aftonbladet.se/kultur/a/BJBdg9/muslimer-ettlovligt-byte

Gemzöe, L. (2018). Solidarity in head-scarf and pussy bow blouse: Reflections on feminist activism and knowledge production. Social Inclusion, 6(4), 67-81.

Giritli Nygren, K., Fahlgren, S., \& Johansson, A. (2016). Normalization meets governmentality: Gender equality reassembled. In L. Martinsson, G. Griffin, \& K. Giritli Nygren (Eds.), Challenging the myth of gender equality in Sweden (pp. 69-92). London: Policy Press.

Helseth, H. (2018). When the personal is always political: Norwegian muslims' arguments for women's rights. Social Inclusion, 6(4), 59-66.

Kaplan, C., \& Grewal, I. (2002) Transnational practices and interdisciplinary feminist scholarship: Refiguring women's and gender studies. In R. Wiegman (Ed.), Women's studies on its own (pp. 66-81). Durham, NC: Duke University.

Kolankiewicz, M. (2015). Anti-Muslim violence and the possibility of justice. Lund: Department of Sociology, Faculty of Social Sciences, Lund University.

Koslowski, A., \& Duvander, A.-Z. (2018). Basic income: The potential for gendered empowerment? Social Inclusion, 6(4), 8-15.

Kundnani, A. (2015). The Muslims are coming: Islamophobia, extremism and the domestic war on terror. London: Verso.

Lilja, M., \& Johansson, E. (2018). Feminism as power and resistance: An inquiry into different forms of Swedish feminist resistance and anti-genderist reactions. Social Inclusion, 6(4), 82-94.

Listerborn, C. (2015). Geographies of the veil: Violent encounters in urban public spaces in Malmö, Sweden. Social and Cultural Geography, 2015(1), 95-115.

Lundqvist, Å. (2017). Transforming gender and family relations. How active labour market policies shaped the dual earner model. London: Edward Elgar Publishing.

Martinsson, L. (2001). Marmorhallen [The marblehall]. In B. Lundgren \& L. Martinsson (Eds.), Bestämma, benömna, betvivla [Decide, denominate, doubt] (pp. 17-45). Lund: Studentlitteratur.

Martinsson, L., Griffin, G., \& Giritli Nygren, K. (2016). Challenging the myth of gender equality in Sweden. Bristol: Policy Press.

Martinsson, L., \& Mulinari, D. (2018). Dreaming global change, doing local feminisms. Visions of feminism: Global North/Global South encounters, conversations and disagreements. London: Routledge.

McDowell, L., \& Sharp, J. (2016). Space, gender, knowledge: Feminist readings. London: Routledge.

Mohanty, C. (2003). Feminism without borders: Decolonizing theory, practicing solidarity. Durham: Duke University Press.

Mulinari, D. (2016). Gender equality under threat? Exploring the dilemmas of an Ethno-Nationalist Political party. In L. Martinsson, G. Griffin, \& K. Giritli Ny- 
gren (Eds.), Challenging the myth of gender equality in Sweden (pp. 137-162). Bristol: Policy Press.

Mulinari, P. (2018). A new service class in the public sector? The role of femonationalism in unemployment policies. Social Inclusion, 6(4), 36-47.

Norocel, O. C. (2010). Constructing radical right populist resistance: Metaphors of heterosexist masculinities and the family question in Sweden. NORMA: Nordic Journal for Masculinity Studies, 5(2), 169-183.

Puar, J. (2017). Terrorist assemblages. Homonationalism in queer times. Durham: Duke University Press.

Rivera Cusicanqui, S. (2010). The notion of 'rights' and the paradoxes of postcolonial modernity: Indigenous peoples and women in Bolivia. Qui Parle: Critical Humanities and Social Sciences, 18(2), 29-54.

Roodsaz, R., \& Van Raemdonck, A. (2018). The traps of international scripts: Making a case for a critical anthropology of gender and sexuality in development. Social Inclusion, 6(4), 16-24.

Schierup, C.-U., \& Ålund, A. (2011). The end of Swedish exceptionalism? Race \& Class, 53(1), 45-64.

Sjöstedt Landén, A., \& Fotaki, M. (2018). Gender and struggles for equality in mining resistance movements: Performing critique against neoliberal capitalism in Sweden and Greece. Social Inclusion, 6(4), 25-35.

Sverker, J. (2018). Christian-Democrats criticism: When boys and girls are excluded from the teaching plan. Dagen. Retrieved from www.dagen.se/nyheter/kdkritik-nar-pojke-och-flicka-stryks-i-forskolans-laroplan $-1.1187492$

Sweden Government. (2018). Gender equality in Sweden. Sweden.se. Retrieved from sweden.se/society/ gender-equality-in-sweden

Therborn, G. (2018). Kapitalet, Överheten och alla vi andra [Capital, the super class and all of us others]. Lund: Arkiv förlag.

Wottle, M., \& Blomberg, E. (2011). Feminism och jämställdhet $\mathrm{i}$ en nyliberal kontext 1990-2010 [Feminism and gender equality in a neo-liberal context 1990-2010]. Tidskrift för Genusvetenskap, 2011(2/3), 97-115.

Wright, O. E. (2009). Envisioning real utopias. London: Verso.

\section{About the Authors}
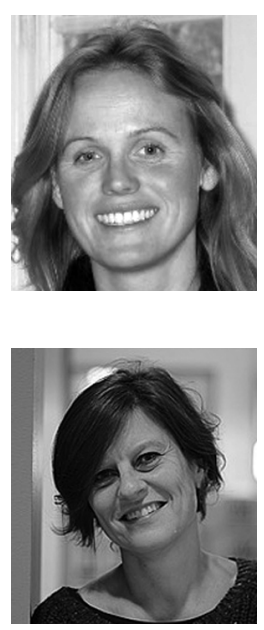

Lena Martinsson is Professor in Gender Studies at the University of Gothenburg, Sweden. Her main research interests are political subjectivity, social movements and transnationalism in the field of feminist and post/ decolonial studies. Her recent publications include Challenging the Myth of Gender Equality in Sweden (edited by L. Martinsson, G. Griffin and K. Giritli Nygren, 2016, Policy Press), Education and Political Subjectivities in Neoliberal Times and Places. Emergences of Norms and Possibilities (edited by E. Reimers L. and Martinsson, 2017, Routledge) and Dreaming Global Change, Doing Local Feminisms (2018, Routledge).

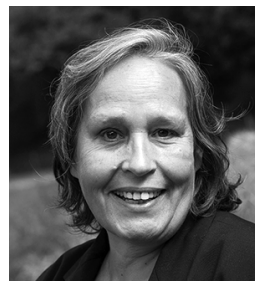

Diana Mulinari is Professor of Gender Studies at the Univeristy of Lund, Sweden. Fundamental topics in her resarach agenda are the exploration of colonial legacies, Global North/Global South relations (with special focus on Latin America) gendered racism (with special focus on Sweden and Western Europe) as well as transnational feminist inspired forms of resistance. Recent published work include the chapter "Putting (Left) Politics Back into (Western) Feminist Theory. Conversations with Feminist Activist and Scholars in Argentina" in Dreaming Global Change, Doing Local Feminisms (2018, Routledge), and the article "Exploring Femonationalism and Care-Racism in Sweden" in Women's Studies International Forum, 68(May/June), 149-156. 